\title{
Prognostic Factors for Colorectal Cancer Patients Treated With Combination of Immune-cell Therapy and First-line Chemotherapy: A Retrospective Study
}

\author{
RISHU TAKIMOTO ${ }^{1,2}$, TAKASHI KAMIGAKI ${ }^{1,2}$, SACHIKO OKADA $^{1}$, ERIKO MATSUDA $^{1}$, \\ HIROSHI IBE ${ }^{1}$, ERI OGUMA ${ }^{1}$, KEIKO NAITOH ${ }^{1}$, KAORI MAKITA ${ }^{1}$ and SHIGENORI GOTO ${ }^{1,2}$ \\ ${ }^{1}$ Seta Clinic Group, Tokyo, Japan; \\ ${ }^{2}$ Department of Next Generation Cell and Immune Therapy, \\ Graduate School of Medicine, Juntendo University, Tokyo, Japan
}

\begin{abstract}
Background/Aim: In this retrospective study, we aimed to investigate the efficacy of immune-cell therapy using $T$ lymphocytes activated in vitro with or without dendritic cells vaccination (DCs), in combination with 1 stline chemotherapies in terms of the survival of patients with advanced colorectal cancer (CRC). Patients and Methods: A total of 198 patients who were diagnosed with advanced CRC and administered 1st-line chemotherapies were enrolled in this study. The correlation between overall survival (OS) and various clinical factors was examined by univariate and multivariate analyses. Results: Univariate analyses revealed that the prognosis was improved in CRC patients who received immune-cell therapy with $P S O$, bevacizumab $(B V)$, and capecitabine-including regimens (Cap). Finally, multivariate analysis demonstrated that $P S=0$, and the combination of immune-cell therapy and Cap provided a survival benefit in patients with advanced CRC. Conclusion: The survival benefit could be potentially obtained with better PS by the combination of immune-cell therapy and Cap as a 1st-line setting in patients with CRC.

Colorectal cancer (CRC) is one of the most prevalent cancers and remains one of the leading causes of cancer-related mortality worldwide (1). The evolution of chemotherapy for patients with CRC has involved a series of landmark advances, such as the discovery of 5-fluorouracil (5-FU) (2), the identification of reduced folate leucovorin as a clinical potentiator of 5-FU cytotoxicity (3), and the advent of novel
\end{abstract}

Correspondence to: Rishu Takimoto, Director, Seta Clinic Tokyo, Seta Clinic Group, New Surugadai Bldg. 3F, 2-1-45 Kandasurugadai, Chiyoda-ku, Tokyo 101-0062, Japan. Tel: +81 352800086, Fax: +81 352800087, e-mail: takimoto@j-immunother.com

Key Words: Immune-cell therapy, colorectal cancer, prognostic factors, $\alpha \beta$ T cell therapy, dendritic cell vaccine. cytotoxic agents, which led to the development of combination chemotherapies such as FOLFOX and FOLFIRI (4-6). Furthermore, the introduction of molecular targeting drugs, such as anti-vascular endothelial growth factor (VEGF) and anti-epidermal growth factor receptor (EGFR) antibodies, has further improved the prognosis of patients with metastatic CRC. Although the development of combination chemotherapies has extended the median survival period of patients with advanced CRC to more than 25 months, half of the patients eventually die from the disease (7). Thus, it is imperative to develop novel therapies for patients with CRC.

The immune system can protect the host from tumorigenesis through immune surveillance mechanisms (8, 9). One of the mechanisms attributed to the occurrence or development of cancer is the deficiency of the immune system. Various strategies have been developed to improve the immune function of cancer patients, which include the use of cytokines, cancer vaccines, checkpoint inhibitors, and adoptive cell transfer (ACT). ACT using tumor-infiltrating lymphocytes (TILs) for CRC patients was first applied in the 1990s (10); however, there was no significant difference in disease-free survival between the TIL-treated group and the conventional chemotherapy-treated group. ACT utilizing cytokine-induced killer cells (CIK) has also been shown to be safe for CRC patients, decrease the recurrence of CRC, and improve OS $(11,12)$.

Recently, the combination of CIK and dendritic cells (DCs) (CIK/DCs) has been actively pursued in the immunotherapy research field. It has been reported that ACT using CIK/DCs could inhibit disease progression and improve OS in patients with CRC (13-15). A combination of immune-cell therapy and conventional chemotherapy was also tested and showed a significant improvement in OS of patients with CRC (16). Furthermore, several studies have demonstrated that CRC patients with liver metastasis could undergo surgical resection after a combination of 


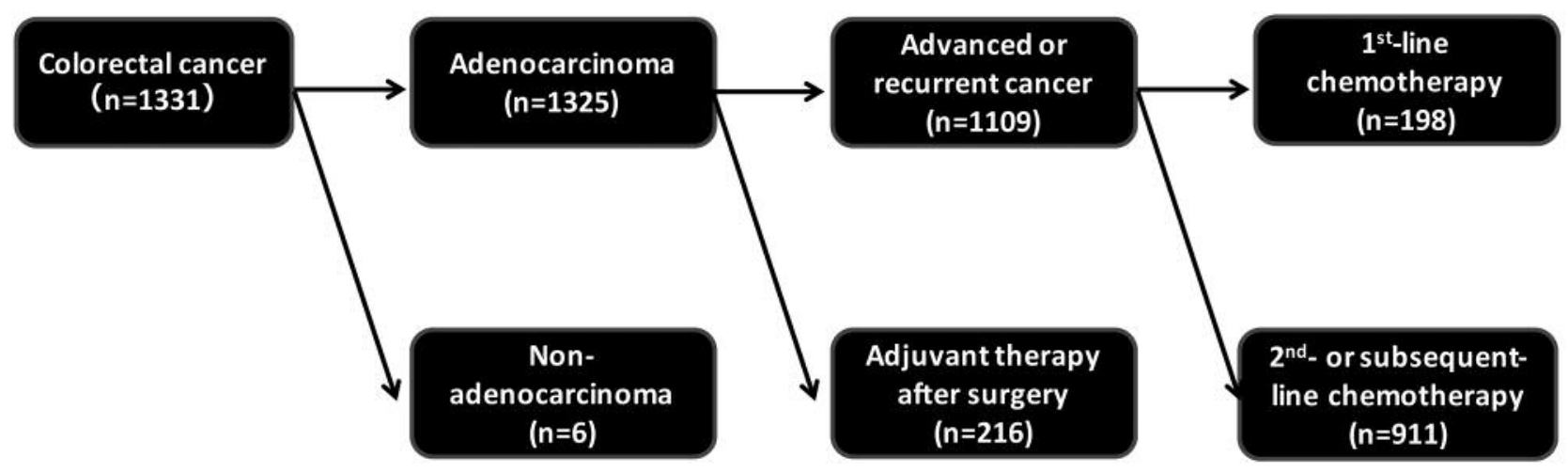

Figure 1. Selection procedure for patients enrolled in this study.

chemotherapy and immune-cell therapy (17-19). However, the efficacy and prognostic factors of immune-cell therapy combined with 1st-line chemotherapy in a large number of patients with CRC remain unclear. In this study, we retrospectively analyzed patients with advanced CRC who had been administered immune-cell therapy as the 1st-line setting at the clinics of the Seta Clinic Group.

\section{Patients and Methods}

Patients. The database of patients administered immune-cell therapy at the clinics of the Seta Clinic Group was searched to identify patients with CRC. As a result, 1,331 patients were identified and enrolled in this study, and we retrospectively reviewed the medical records of those administered $\alpha \beta T$ cell therapy, DC vaccine therapy, or a combination of both between 1999 and 2015. The study protocol was approved by the Research Ethics Committee of the Seta Clinic Group. Available data on age, sex, performance status (PS) score on the Eastern Cooperative Oncology Group (ECOG) scale, metastasis sites, tumor location, clinical stage, treatments, and vital status were extracted from the medical records of the patients.

Treatment. For $\alpha \beta T$ cell therapy, activated lymphocytes were generated as previously described (20). In brief, peripheral blood mononuclear cells (PBMCs) were isolated from a patient's peripheral blood using Vacutainer (Becton, Dickinson and Company, Franklin Lakes, NJ, USA). The PBMCs were activated in a culture flask with an immobilized monoclonal antibody to CD3 (Jansen-Kyowa, Tokyo, Japan) in Hymedium 930 (Kohjin Bio, Saitama, Japan) containing $1 \%$ autologous serum. The PBMCs were then cultured for 14 days with $700 \mathrm{IU} / \mathrm{ml}$ recombinant interleukin-2 (IL-2) (Proleukin ${ }^{\circledR}$; Chiron, Amsterdam, the Netherlands), after which, $3-10 \times 10^{9}$ cells were harvested and suspended in $100 \mathrm{ml}$ of normal saline for intravenous injection. To prepare a DC vaccine, PBMCs were collected from the patients by leukapheresis and allowed to adhere to a plastic culture flask. The adherent cell fraction was used for DC culture for 6 days using a medium supplemented with $50 \mathrm{ng} / \mathrm{ml}$ IL4 (Primmune Corp., Osaka, Japan) and $50 \mathrm{ng} / \mathrm{ml}$ granulocyte macrophage colonystimulating factor (GM-CSF) (Primmune Corp.) to generate immature DCs. The DCs were pulsed with antigenic tumorspecific peptides or an autologous tumor lysate and allowed to mature for $24 \mathrm{~h}$. After the culture, $1-10 \times 10^{6}$ mature DCs were harvested and suspended in $1 \mathrm{ml}$ of normal saline for subcutaneous injection, and then cryopreserved until the day of administration. Immune-cell therapy consists of $\alpha \beta T$ cell therapy, DC vaccine therapy, or both and is commonly administered 6 times, that is, every 2 weeks for 3 months, as one course.

Assessment. OS was defined as the length of time from the initial administration of immune-cell therapy to death from any cause and calculated for every patient. The Kaplan-Meier method was used to calculate survival probabilities for all patients.

Statistical analyses. OS was examined by the Kaplan-Meier analysis with the Wilcoxon test, and the hazard ratio was obtained by Cox regression methods in univariate and multivariate analyses. All statistical analyses were two-sided and performed using JMP, version 11.2.0 for Microsoft Windows 7 (SAS, Cary, NC, USA). Differences were considered statistically significant when $p<0.05$.

\section{Results}

Patient selection. A total of 1,331 patients with CRC were enrolled in this study (Figure 1). Among them, 1,325 patients were confirmed to have CRC by biopsy or suspected to have adenocarcinoma on the basis of diagnostic imaging findings, and six patients had malignant solid tumors other than adenocarcinoma. Of the 1,325 patients, 1,109 had advanced or recurrent CRC (216 patients were excluded because immune-cell therapy was performed as an adjuvant therapy after surgery). Finally, to examine the efficacy of immunecell therapy combined with a 1 st-line chemotherapy, we selected 198 patients with CRC (Figure 1).

The patients' characteristics are summarized in Table I. In this study, the correlation between OS and various factors including sex, age, PS, clinical stage, tumor location, chemotherapy, radiation therapy, and immune-cell therapy were evaluated by univariate analysis and multivariate Cox regression analysis. 
Table I. Patient characteristics.

\begin{tabular}{|c|c|}
\hline Characteristic & Number of cases $(\%)$ \\
\hline Total, $\mathrm{n}$ & 198 \\
\hline Male & $100(50.5)$ \\
\hline Female & $98(49.5)$ \\
\hline Median age (range), years & $62(29-84)$ \\
\hline$\geq 62$ & $99(50.0)$ \\
\hline$<62$ & $99(50.0)$ \\
\hline \multicolumn{2}{|l|}{ Performance status } \\
\hline 0 & $144(72.7)$ \\
\hline $1-4$ & $54(27.3)$ \\
\hline \multicolumn{2}{|l|}{ Clinical Stage } \\
\hline II & $8(4.0)$ \\
\hline III & $50(25.3)$ \\
\hline IV & $115(58.1)$ \\
\hline Unknown & $25(12.6)$ \\
\hline \multicolumn{2}{|l|}{ Location } \\
\hline Colon & $125(63.1)$ \\
\hline Rectum & $73(36.9)$ \\
\hline \multicolumn{2}{|l|}{ Left/Right side } \\
\hline Left (Rectum/Sigmoid/Descending) & $123(62.1)$ \\
\hline Right (Transverse/Ascending/Ileum) & $67(33.8)$ \\
\hline \multicolumn{2}{|l|}{ Treatment } \\
\hline \multicolumn{2}{|l|}{ Operation } \\
\hline Yes & $176(88.9)$ \\
\hline No & $22(11.1)$ \\
\hline \multicolumn{2}{|l|}{ Chemotherapy } \\
\hline Yes & $198(100)$ \\
\hline No & $0(0)$ \\
\hline \multicolumn{2}{|l|}{ Radiation therapy } \\
\hline Yes & $26(13.1)$ \\
\hline No & $172(86.9)$ \\
\hline \multicolumn{2}{|l|}{ Immunotherapy } \\
\hline$\alpha \beta \mathrm{T}$ & $156(78.8)$ \\
\hline$\alpha \beta T+D C$ & $42(21.2)$ \\
\hline
\end{tabular}

$\alpha \beta T$ : Activated lymphocyte therapy; DC: dendritic cell vaccine therapy.

Overall survival. The median age of the 198 patients (99 males and 99 females) with advanced or recurrent CRC was 62 years (range $=29-84$ years, Table I). The median survival time (MST) of patients with advanced or recurrent CRC was 21.2 months since the administration of immune-cell therapy has started, and the 3- and 5-year OS rates were $25.9 \%$ and $9.4 \%$, respectively (Figure 2). There was no significant difference in survival time in relation to sex, age, clinical stage, and tumor location; however, a significant difference was observed in relation to PS (Figure 3). The analysis of survival time demonstrated that the MSTs of the patients with a PS score of 0 and those with PS scores of 1-4 were 26.0 and 12.7 months, respectively ( $p=0.0003$; Figure $3 C$ ).

We then examined the effect of treatment strategy on the survival time of patients with CRC (Tables I and II). There was no significant difference in survival time in relation to

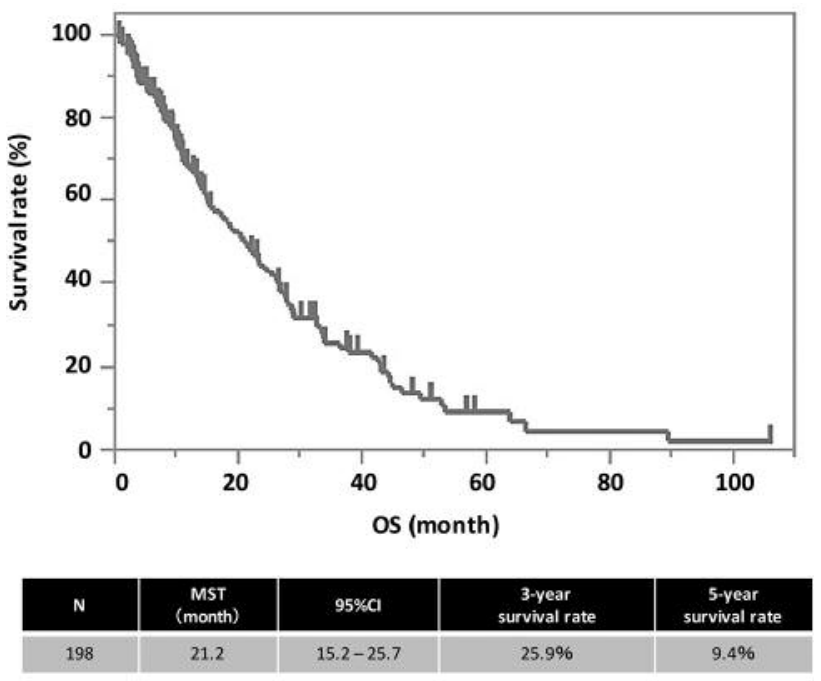

Figure 2. Kaplan-Meier estimates of overall survival in the full analysis set. OS: Overall survival (months); MST: median survival time.

Table II. Items of chemotherapeutic agents.

\begin{tabular}{lc}
\hline Classification & Number of cases \\
\hline BV & \\
Yes & 64 \\
No & 130 \\
1st-line agents & 29 \\
Capecitabine-including regimens & 83 \\
FOLFOX/FOLFIRI-including regimens & 13 \\
TS1 & \\
\hline
\end{tabular}

BV: Bevacizumab; FOLFOX: fluorouracil+folinic acid+oxaliplatin; FOLFIRI: fluorouracil+folinic acid+irinotecan; TS1: tegafur/gimeracil/ oteracil.

the combination of immune-cell therapy and surgical operation or radiation therapy (Figure 4A and 4B). Of the 198 CRC patients treated with immune-cell therapy, 156 received $\alpha \beta \mathrm{T}$ cell therapy alone and 42 received both DC vaccine therapy and $\alpha \beta \mathrm{T}$ cell therapy $(\mathrm{DC}+\alpha \beta \mathrm{T})$. Regarding survival analysis by the type of immune-cell therapy administered, there was a significant difference in MST between patients treated with DCs $+\alpha \beta T$ cells and those treated with $\alpha \beta \mathrm{T}$ cells only (26.5 and 20.0 months, respectively; $p=0.0253$, Figure $4 C$ ). We then examined whether the type of 1st-line chemotherapy combined with immune-cell therapy affected OS in patients with CRC (Table II, Figure 5). Kaplan-Meier analysis by the Wilcoxon test showed that the MST of bevacizumab (BV)-treated patients was longer than that of non-BV-treated patients (26.5 vs. 14.3 months; $p=0.0002$, Figure 5A). Furthermore, 

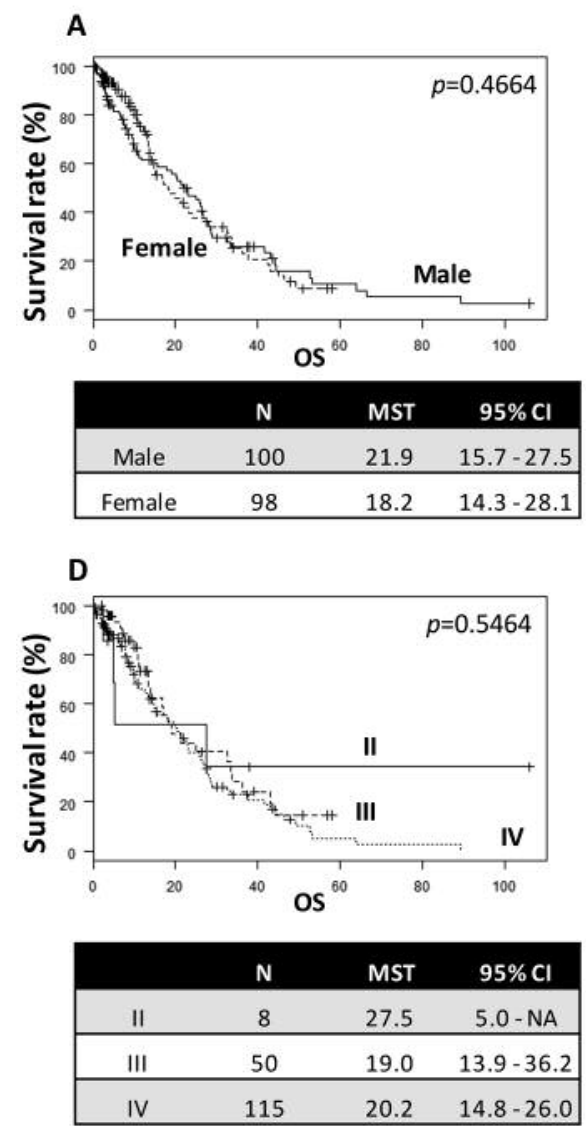

B

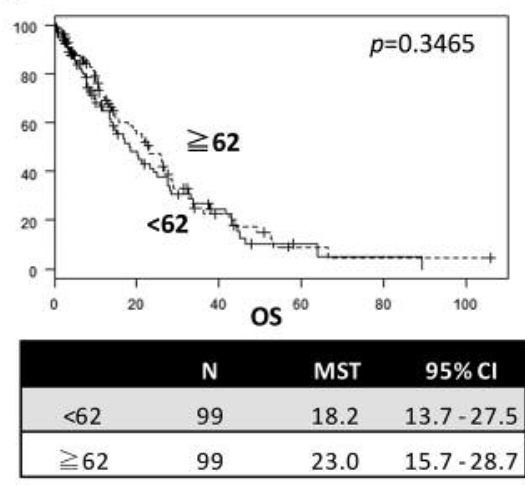

E

C

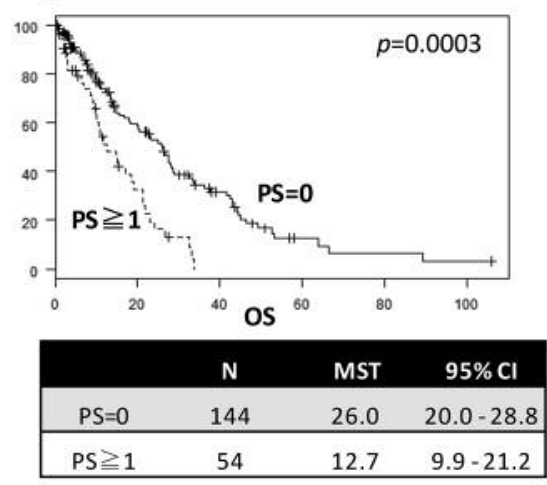

$\mathbf{F}$
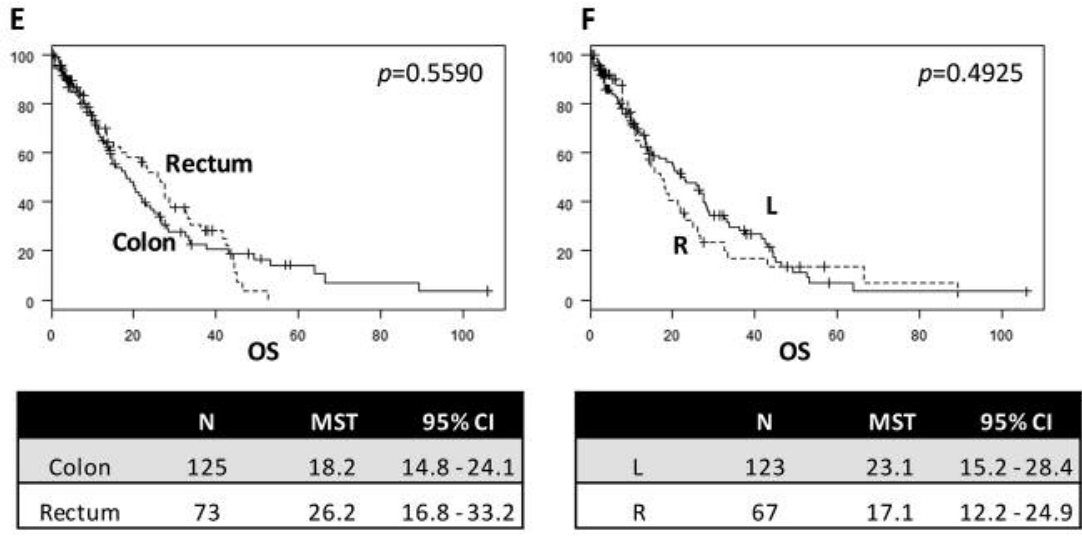

Figure 3. Correlation of Kaplan-Meier estimates of overall survival with sex (A), age (B), performance status $(C)$, clinical stage (D), and tumor location (E, colon and rectum; F, right and left). OS: Overall survival; MST: median survival time.

there was a significant difference in MST between patients treated with capecitabine-including regimens and those treated with FOLFOX/FOLFIRI or TS1-including regimens (32.5 vs. 20.0 vs. 13.7 months, $p=0.0023$, Figure 5B).

Univariate and multivariate analyses. The univariate analyses of patients' characteristics demonstrated that PS was one of the independent prognostic factors for CRC patients ( $\mathrm{HR}=0.410$; 95\% CI $=0.271-0.631 ; p<0.0001$, Table III). Regarding treatments with chemotherapeutic agents, the univariate analyses revealed that the prognosis was improved in the patients with $\mathrm{CRC}$ who received immune-cell therapy with $\mathrm{BV}$ (HR=0.553; 95\%CI=0.368-0.816; $p=0.0026$, Table IV). The prognosis was also improved in the patients who received immune-cell therapy combined with capecitabine-including regimens compared with those who received FOLFOX/ FOLFIRI $(\mathrm{HR}=2.256 ; 95 \% \mathrm{CI}=1.285-4.197 ; p=0.0040)$ or TS1 $(\mathrm{HR}=3.684 ; 95 \% \mathrm{CI}=1.578-8.264 ; p=0.0034)$ (Table IV).

Finally, multivariate analysis demonstrated that $\mathrm{PS}=0$ indicated a better prognosis in CRC patients treated with immune-cell therapy $(\mathrm{HR}=0.334 ; 95 \% \mathrm{CI}=0.194-0.589$; $p=0.0002$, Table V). Additionally, capecitabine-including regimens with immune-cell therapy improved survival in advanced CRC patients compared with FOLFOX/FOLFIRI $(\mathrm{HR}=2.174 ; 95 \% \mathrm{CI}=1.226-4.078 ; p=0.0071)$ and $\mathrm{TS} 1$ $(\mathrm{HR}=3.138 ; 95 \% \mathrm{CI}=1.305-7.289 ; p=0.0117)$. Thus, it was indicated that PS and capecitabine-including regimens were independent prognostic factors for patients with CRC treated with 1 st-line chemotherapy and immune-cell therapy.

\section{Discussion}

Although the development of combination chemotherapies has prolonged the median survival length of patients with advanced CRC to more than 25 months, many CRC patients suffer from poor prognosis owing to relapse or metastasis, especially for advanced tumors (1). Conventional treatments, including surgery, chemotherapy, and radiotherapy, may induce various adverse effects and impair the patients' antitumor immunity, resulting in residual tumor. In this retrospective study, we extracted 198 patients with CRC from 1,331 patients who have visited our clinic and diagnosed as having colorectal tumor, and we analyzed the 
A

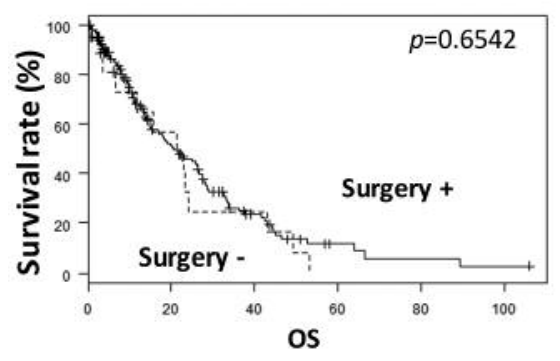

\begin{tabular}{|cccc|}
\hline & N & MST & $95 \% \mathrm{Cl}$ \\
\hline Surgery + & 176 & 20.5 & $15.2-26.5$ \\
\hline Surgery - & 22 & 21.4 & $11.7-\mathrm{NA}$ \\
\hline
\end{tabular}
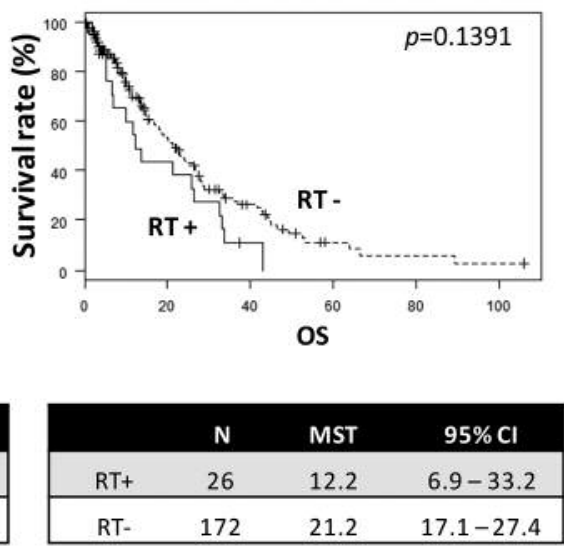

C

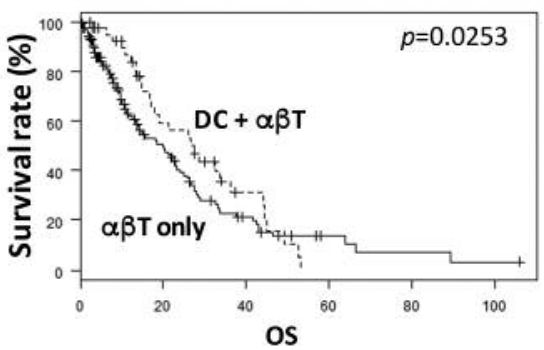

\begin{tabular}{|cccc|}
\hline & N & MST & $95 \% \mathrm{Cl}$ \\
\hline$\alpha \beta T$ only & 156 & 20.0 & $13.9-24.9$ \\
\hline$\alpha \beta T+D C$ & 42 & 26.5 & $17.8-44.1$ \\
\hline
\end{tabular}

Figure 4. Correlation of Kaplan-Meier estimates of overall survival with surgical operation (A), radiation therapy (B), and immune-cell therapy (C). OS: Overall survival; MST: median survival time; RT: radiation therapy; $\alpha \beta T$ : $\alpha \beta T$ immune-cell therapy; DC: dendritic cell vaccive therapy.

A

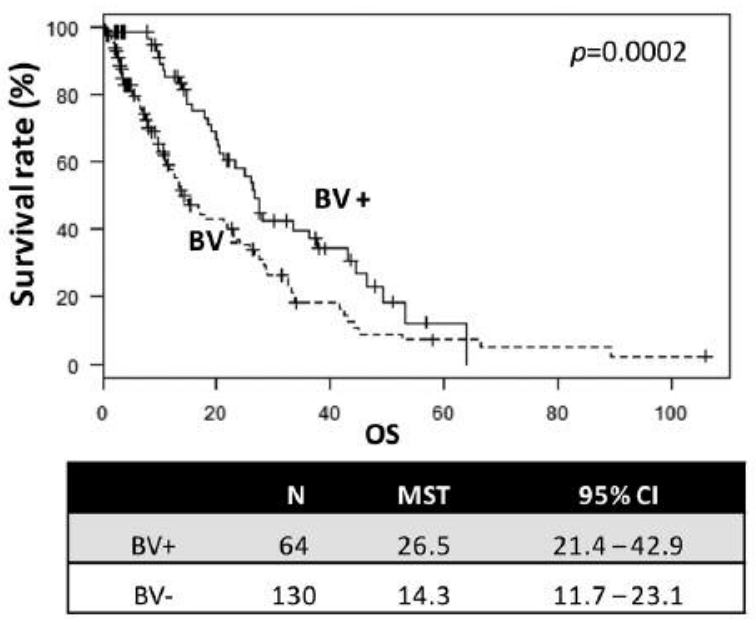

B

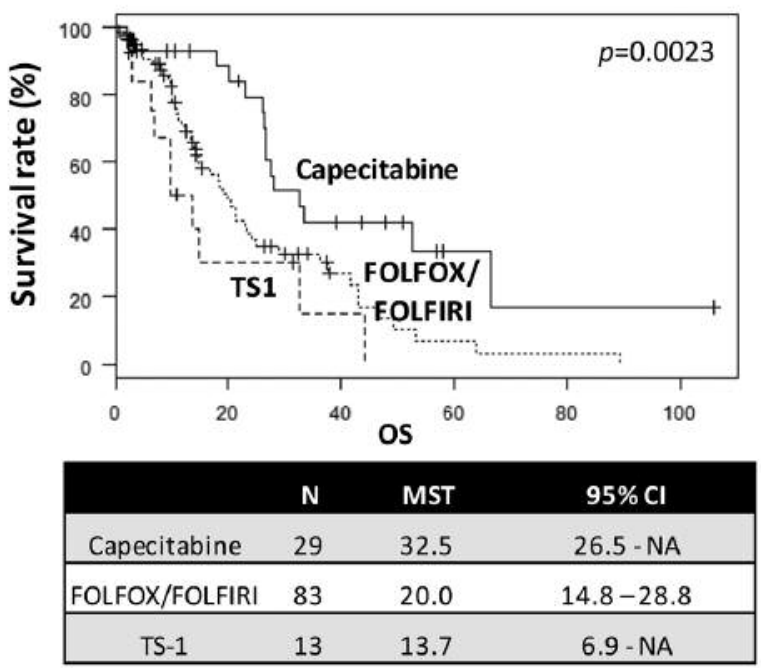

Figure 5. Kaplan-Meier estimates of overall survival according to treatment with or without bevacizumab (A) and type of chemotherapy (B). OS: Overall survival; MST: median survival time; BV: bevacizumab; FOLFOX: fluorouracil+folinic acid+oxaliplatin; FOLFIRI: fluorouracil+folinic acid+irinotecan; TS1: tegafur/gimeracil/oteracil.

efficacy of immune-cell therapy combined with a 1st-line chemotherapy. As a result, we observed an increased efficacy of immune-cell therapy as a 1st-line setting for patients with metastatic CRC.

In the comparison between immune-cell therapy alone and that combined with other treatments, several studies have demonstrated that a combination therapy shows better therapeutic effects than immune-cell therapy alone (Figures 4 and 5 and Table V) (17-19). In our study, the combination of immune-cell therapy and chemotherapy, especially BV or capecitabine chemotherapy, provided a survival benefit in the advanced or recurrent CRC patients (Figure 5). This benefit can be explained by the reinforcement of the immune system via the actions of anticancer agents; for example, suppressive regulatory $\mathrm{T}$ cells were found to be depleted by several chemotherapeutic agents, resulting in enhanced T-cell reactivity $(21,22)$. Oxaliplatin induces the immunogenic death of colorectal cancer cells, and this effect determines its therapeutic 
Table III. Univariate analyses of overall survival in relation to clinical background.

\begin{tabular}{llcc}
\hline Characteristics & HR & $95 \%$ CI & $p$-Value \\
\hline $\begin{array}{l}\text { Gender } \\
\text { M }\end{array}$ & 1 & & \\
$\quad$ F & 0.969 & $0.665-1.404$ & 0.8673 \\
Age, years & & & \\
$\quad<62$ & 1 & & \\
$\quad \geq 62$ & 0.869 & $0.602-1.253$ & 0.4497 \\
PS & & & \\
$\quad \geq 1$ & 1 & & \\
$\quad 0$ & 0.410 & $0.271-0.631$ & $<0.0001$ \\
Clinical stage & & & \\
II & 1 & & 0.5910 \\
$\quad$ III & 1.332 & $0.503-4.623$ & \\
$\quad$ IV & 1.704 & $0.690-5.690$ & 0.2733 \\
Location & & & \\
$\quad$ Rectum & 1 & & \\
$\quad$ Colon & 1.009 & $0.692-1.482$ & 0.9632 \\
Left/Right & 1 & & \\
$\quad$ Right & 0.881 & $0.596-1.324$ & 0.5336 \\
$\quad$ Left & & & \\
\hline
\end{tabular}

PS: Performance status.

Table IV. Univariate analyses of overall survival in relation to therapy.

\begin{tabular}{llcc}
\hline Characteristics & HR & $95 \% \mathrm{CI}$ & $p$-Value \\
\hline $\begin{array}{l}\text { Immune-cell therapy } \\
\alpha \beta \mathrm{T}\end{array}$ & 1 & & \\
$\quad \begin{array}{l}\alpha \mathrm{T}+\mathrm{DC} \\
\text { Radiation therapy }\end{array}$ & 0.752 & $0.482-1.140$ & 0.1839 \\
$\quad$ No & 1 & & \\
$\quad$ Yes & 1.572 & $0.916-2.549$ & 0.0970 \\
Surgical operation & & & \\
$\quad$ No & 1 & & \\
$\quad$ Yes & 0.823 & $0.478-1.542$ & 0.5203 \\
BV & & & \\
$\quad$ No & 1 & & \\
$\quad$ Yes & 0.553 & $0.368-0.816$ & 0.0026 \\
$\begin{array}{l}\text { 1st-line agents } \\
\text { Capecitabine }\end{array}$ & 1 & & \\
$\quad$ FOLFOX/FOLFIRI & 2.256 & $1.285-4.197$ & 0.0040 \\
$\quad$ TS1 & 3.684 & $1.578-8.264$ & 0.0034 \\
\hline
\end{tabular}

$\alpha \beta T$ : Activated lymphocyte therapy; DC: dendritic cell vaccine therapy; BV: bevacizumab; FOLFOX: fluorouracil+folinic acid+oxaliplatin; FOLFIRI: fluorouracil+folinic acid+irinotecan; TS1: tegafur/gimeracil/ oteracil.

efficacy in patients with CRC (23). BV, which is an antibody against VEGF, can enhance the antitumor activity of adoptively transferred antitumor T-cells (24). A previous study has shown that 5-FU can up-regulate tumor antigen expression and MHC class I expression in CRC and breast cancer cells (25).
Table V. Multivariable analyses of overall survival in relation to therapy.

\begin{tabular}{llll}
\hline Characteristics & HR & 95\%CI & $p$-Value \\
\hline PS & & & \\
$\quad \geq 1$ & 1 & & \\
0 & 0.334 & $0.194-0.589$ & 0.0002 \\
BV & & & \\
$\quad$ No & 1 & & \\
$\quad$ Yes & 0.740 & $0.443-1.238$ & 0.2501 \\
1st-line agents & & & \\
$\quad$ Capecitabine & 1 & & \\
FOLFOX/FOLFIRI & 2.174 & $1.226-4.078$ & 0.0071 \\
TS1 & 3.138 & $1.305-7.289$ & 0.0117 \\
\hline
\end{tabular}

PS: Performance status; BV: bevacizumab; FOLFOX: fluorouracil+ folinic acid+oxaliplatin; FOLFIRI: fluorouracil+folinic acid+irinotecan; TS1: tegafur/gimeracil/oteracil.

Furthermore, it has been demonstrated that 5-FU selectively kills tumor-associated myeloid-derived suppressor cells (MDSCs) resulting in the up-regulation of T-cell-dependent antitumor immunity (26-28). Capecitabine, a prodrug of 5-FU, has also been reported to reverse tumor escape by inhibiting MDSCs more effectively than 5-FU could (29). Thus, these findings suggest that chemotherapeutics can provide several beneficial effects on the immune system, resulting in the improvement of the patient's prognosis (30).

Recently, it has been shown that patients with microsatellite instability-high (MSI-H) CRC showed better response to antiPD-1 antibodies (e.g., nivolumab and pembrolizumab) than those with MSI-low (MSI-L) CRC $(31,32)$. MSI is caused by mutations in a mismatch repair (MMR) gene with the consequent inability to correct DNA errors during cell replication (33). It is now recommended that the MSI status should be evaluated in all newly diagnosed CRC cases, because the MSI-H status increases the expression levels of neoantigens owing to the high genomic instability in such cases (34), leading to the enhancement of local immune responses (35). Note that pembrolizumab is now approved in Japan for patients with advanced cancers with MSI-H including CRC. Since immune-cell therapy potentiates the immune reaction against cancer cells, the combination of check-point inhibitors (e.g., pembrolizumab and nivolumab) and immune-cell therapy could be a promising immunotherapy for MSI-H CRC patients.

In conclusion, a better prognosis could be obtained with better PS by the combination of immune-cell therapy and chemotherapy with the normal immune-cell function preserved. However, to establish a comprehensive immunotherapy for $\mathrm{CRC}$, it is necessary to conduct a randomized trial to further elucidate the benefits of the combination of immune-cell therapy and various other treatments, such as chemotherapy, radiotherapy, or therapy with immune check-point inhibitors. 


\section{Conflicts of Interest}

The Authors declare that there are no potential conflicts of interest in relation to this study.

\section{Authors' Contributions}

Conception and design: R. Takimoto, T. Kamigaki, and S. Goto; Administrative support: S. Okada, E. Matsuda, H. Ibe, and E. Oguma; Collection and assembly of data: S. Okada, E. Matsuda, H. Ibe, E. Oguma, K. Naitoh, K. Makita and K. Yasumoto; Data analysis and interpretation: R. Takimoto, S. Okada, T. Kamigaki, and S. Goto; Final approval of manuscript: All Authors.

\section{References}

1 Ferlay J, Steliarova-Foucher E, Lortet-Tieulent J, Rosso S, Coebergh JW, Comber H, Forman D and Bray F: Cancer incidence and mortality patterns in europe: Estimates for 40 countries in 2012. Eur J Cancer 49(6): 1374-1403, 2013. PMID: 23485231. DOI: 10.1016/j.ejca.2012.12.027

2 Heidelberger C, Chaudhuri NK, Danneberg P, Mooren D, Griesbach L, Duschinsky R, Schnitzer RJ, Pleven E and Scheiner J: Fluorinated pyrimidines, a new class of tumourinhibitory compounds. Nature 179(4561): 663-666, 1957. PMID: 13418758

3 Poon MA, O'Connell MJ, Moertel CG, Wieand HS, Cullinan SA, Everson LK, Krook JE, Mailliard JA, Laurie JA and Tschetter LK: Biochemical modulation of fluorouracil: Evidence of significant improvement of survival and quality of life in patients with advanced colorectal carcinoma. J Clin Oncol 7(10): 1407-1418, 1989. PMID: 2476530. DOI: 10.1200/jco.1989.7 10.1407

4 Saltz LB, Cox JV, Blanke C, Rosen LS, Fehrenbacher L, Moore MJ, Maroun JA, Ackland SP, Locker PK, Pirotta N, Elfring GL and Miller LL: Irinotecan plus fluorouracil and leucovorin for metastatic colorectal cancer. Irinotecan study group. $\mathrm{N}$ Engl J Med 343(13): 905-914, 2000. PMID: 11006366. DOI: 10.1056/nejm200009283431302

5 Goldberg RM, Sargent DJ, Morton RF, Fuchs CS, Ramanathan RK, Williamson SK, Findlay BP, Pitot HC and Alberts SR: A randomized controlled trial of fluorouracil plus leucovorin, irinotecan, and oxaliplatin combinations in patients with previously untreated metastatic colorectal cancer. J Clin Oncol 22(1): 23-30, 2004. PMID: 14665611. DOI: 10.1200/jco.2004. 09.046

6 Colucci G, Gebbia V, Paoletti G, Giuliani F, Caruso M, Gebbia N, Carteni G, Agostara B, Pezzella G, Manzione L, Borsellino N, Misino A, Romito S, Durini E, Cordio S, Di Seri M, Lopez M, Maiello E, Montemurro S, Cramarossa A, Lorusso V, Di Bisceglie M, Chiarenza M, Valerio MR, Guida T, Leonardi V, Pisconti S, Rosati G, Carrozza F, Nettis G, Valdesi M, Filippelli G, Fortunato S, Mancarella S, Brunetti C and Gruppo Oncologico Dell'Italia M: Phase III randomized trial of folfiri versus folfox 4 in the treatment of advanced colorectal cancer: A multicenter study of the gruppo oncologico dell'italia meridionale. J Clin Oncol 23(22): 4866-4875, 2005. PMID: 15939922. DOI: $10.1200 / J C O .2005 .07 .113$

7 Gill S, Blackstock AW and Goldberg RM: Colorectal cancer. Mayo Clin Proc 82(1): 114-129, 2007. PMID: 17285793. DOI: $10.4065 / 82.1 .114$
8 Stoll G, Bindea G, Mlecnik B, Galon J, Zitvogel L and Kroemer G: Meta-analysis of organ-specific differences in the structure of the immune infiltrate in major malignancies. Oncotarget 6(14): 11894-11909, 2015. PMID: 26059437. DOI: 10.18632/ oncotarget 4180

9 Mlecnik B, Tosolini M, Charoentong P, Kirilovsky A, Bindea G, Berger A, Camus M, Gillard M, Bruneval P, Fridman WH, Pages $\mathrm{F}$, Trajanoski $\mathrm{Z}$ and Galon J: Biomolecular network reconstruction identifies t-cell homing factors associated with survival in colorectal cancer. Gastroenterology 138(4): 1429-1440, 2010. PMID: 19909745. DOI: 10.1053/j.gastro.2009. 10.057

10 Gardini A, Ercolani G, Riccobon A, Ravaioli M, Ridolfi L, Flamini E, Ridolfi R, Grazi GL, Cavallari A and Amadori D: Adjuvant, adoptive immunotherapy with tumor infiltrating lymphocytes plus interleukin-2 after radical hepatic resection for colorectal liver metastases: 5-year analysis. J Surg Oncol 87(1): 46-52, 2004. PMID: 15221919 . DOI: 10.1002/jso.20066

11 Schmidt-Wolf IG, Finke S, Trojaneck B, Denkena A, Lefterova P, Schwella N, Heuft HG, Prange G, Korte M, Takeya M, Dorbic T, Neubauer A, Wittig B and Huhn D: Phase I clinical study applying autologous immunological effector cells transfected with the interleukin-2 gene in patients with metastatic renal cancer, colorectal cancer and lymphoma. Br J Cancer 81(6): 1009-1016, 1999. PMID: 10576658. DOI: 10.1038/sj.bjc. 6690800

12 Zhang J, Zhu L, Zhang Q, He X, Yin Y, Gu Y, Guo R, Lu K, Liu L, Liu P and Shu Y: Effects of cytokine-induced killer cell treatment in colorectal cancer patients: A retrospective study. Biomed Pharmacother 68(6): 715-720, 2014. PMID: 25107840. DOI: 10.1016/j.biopha.2014.07.010

13 Gao D, Li C, Xie X, Zhao P, Wei X, Sun W, Liu HC, Alexandrou AT, Jones J, Zhao R and Li JJ: Autologous tumor lysate-pulsed dendritic cell immunotherapy with cytokineinduced killer cells improves survival in gastric and colorectal cancer patients. PLoS One 9(4): e93886, 2014. PMID: 24699863. DOI: 10.1371/journal.pone.0093886

14 Zhu H, Yang X, Li J, Ren Y, Zhang T, Zhang C, Zhang J, Li J and Pang Y: Immune response, safety, and survival and quality of life outcomes for advanced colorectal cancer patients treated with dendritic cell vaccine and cytokine-induced killer cell therapy. Biomed Res Int 2014: 603871, 2014. PMID: 25136601. DOI: $10.1155 / 2014 / 603871$

15 Niu J, Ren Y, Zhang T, Yang X, Zhu W, Zhu H, Li J, Li J and Pang Y: Retrospective comparative study of the effects of dendritic cell vaccine and cytokine-induced killer cell immunotherapy with that of chemotherapy alone and in combination for colorectal cancer. Biomed Res Int 2014: 214727, 2014. PMID: 25210706. DOI: $10.1155 / 2014 / 214727$

16 Mosinska P, Gabryelska A, Zasada M and Fichna J: Dual functional capability of dendritic cells - cytokine-induced killer cells in improving side effects of colorectal cancer therapy. Front Pharmacol 8: 126, 2017. PMID: 28352234. DOI: 10.3389/fphar. 2017.00126

17 Yoshida Y, Naito M, Yamada T, Aisu N, Daibo K, Mera T, Tanaka T, Naito K, Yasumoto K, Kamigaki T, Goto S, Yamashita $\mathrm{Y}$ and Hasegawa S: Adoptive chemoimmunotherapy using activated alphabeta $\mathrm{t}$ cells for stage iv colorectal cancer. Anticancer Res 36(7): 3741-3746, 2016. PMID: 27354648.

18 Ishii F, Yoshida Y, Yamauchi Y, Aisu N, Kojima D, Mera T, Kato D, Tanaka T, Naito K, Yasumoto K, Kamigaki T, Goto S, Hamada Y, Nimura S, Kodama S and Hasegawa S: Hepatectomy for liver 
metastases of colorectal cancer after adoptive chemoimmunotherapy using activated alphabeta t-cells. Anticancer Res 37(7): 3933-3939, 2017. PMID: 28668897. DOI: 10.21873/anticanres.11776

19 Yoshida Y, Naito M, Yamada T, Aisu N, Kojima D, Mera T, Tanaka T, Naito K, Yasumoto K, Kamigaki T, Gotoh S, Kodama S, Yamashita Y and Hasegawa S: Clinical study on the medical value of combination therapy involving adoptive immunotherapy and chemotherapy for stage iv colorectal cancer (comvi study). Anticancer Res 37(7): 3941-3946, 2017. PMID: 28668898. DOI: 10.21873/anticanres.11777

20 Takimoto R, Kamigaki T, Okada S, Matsuda E, Ibe H, Oguma E, Naitoh K, Makita K and Goto S: Efficacy of adoptive immune-cell therapy in patients with advanced gastric cancer: A retrospective study. Anticancer Res 37(7): 3947-3954, 2017. PMID: 28668899

21 Apetoh L, Ghiringhelli F, Tesniere A, Obeid M, Ortiz C, Criollo A, Mignot G, Maiuri MC, Ullrich E, Saulnier P, Yang H, Amigorena S, Ryffel B, Barrat FJ, Saftig P, Levi F, Lidereau R, Nogues C, Mira JP, Chompret A, Joulin V, Clavel-Chapelon F, Bourhis J, Andre F, Delaloge S, Tursz T, Kroemer G and Zitvogel L: Toll-like receptor 4-dependent contribution of the immune system to anticancer chemotherapy and radiotherapy. Nat Med 13(9): 1050-1059, 2007. PMID: 17704786. DOI: $10.1038 / \mathrm{nm} 1622$

22 Galluzzi L, Senovilla L, Zitvogel L and Kroemer G: The secret ally: Immunostimulation by anticancer drugs. Nat Rev Drug Discov 11(3): 215-233, 2012. PMID: 22301798. DOI: 10.1038/ nrd3626

23 Tesniere A, Schlemmer F, Boige V, Kepp O, Martins I, Ghiringhelli F, Aymeric L, Michaud M, Apetoh L, Barault L, Mendiboure J, Pignon JP, Jooste V, van Endert P, Ducreux M, Zitvogel L, Piard F and Kroemer G: Immunogenic death of colon cancer cells treated with oxaliplatin. Oncogene 29(4): 482491, 2010. PMID: 19881547. DOI: 10.1038/onc.2009.356

24 Shrimali RK, Yu Z, Theoret MR, Chinnasamy D, Restifo NP and Rosenberg SA: Antiangiogenic agents can increase lymphocyte infiltration into tumor and enhance the effectiveness of adoptive immunotherapy of cancer. Cancer Res 70(15): 6171-6180, 2010. PMID: 20631075. DOI: 10.1158/0008-5472.CAN-10-0153

25 Correale P, Aquino A, Giuliani A, Pellegrini M, Micheli L, Cusi MG, Nencini C, Petrioli R, Prete SP, De Vecchis L, Turriziani M, Giorgi G, Bonmassar E and Francini G: Treatment of colon and breast carcinoma cells with 5-fluorouracil enhances expression of carcinoembryonic antigen and susceptibility to hla$\mathrm{a}(*) 02.01$ restricted, cea-peptide-specific cytotoxic t cells in vitro. Int J Cancer 104(4): 437-445, 2003. PMID: 12584740. DOI: $10.1002 / \mathrm{ijc} .10969$

26 Vincent J, Mignot G, Chalmin F, Ladoire S, Bruchard M, Chevriaux A, Martin F, Apetoh L, Rebe C and Ghiringhelli F: 5-fluorouracil selectively kills tumor-associated myeloid-derived suppressor cells resulting in enhanced t cell-dependent antitumor immunity. Cancer Res 70(8): 3052-3061, 2010. PMID: 203887 95. DOI: $10.1158 / 0008-5472 . C A N-09-3690$

27 Gabrilovich DI and Nagaraj S: Myeloid-derived suppressor cells as regulators of the immune system. Nat Rev Immunol 9(3): 162-174, 2009. PMID: 19197294. DOI: 10.1038/nri2506
28 Ostrand-Rosenberg S and Sinha P: Myeloid-derived suppressor cells: Linking inflammation and cancer. J Immunol 182(8): 4499-4506, 2009. PMID: 19342621. DOI: 10.4049/jimmunol. 0802740

29 Iwai T, Harada Y, Saeki H, Oki E, Maehara Y and Yonemitsu Y: Capecitabine reverses tumor escape from anti-vegf through the eliminating cd11b(high)/gr1(high) myeloid cells. Oncotarget 9(25): 17620-17630, 2018. PMID: 29707135. DOI: 10.18632/ oncotarget.24811

30 Makita K, Kamigaki T, Okada S, Matsuda E, Ibe H, Oguma E, Naitoh K, Takimoto R and Goto S: Prognostic factors for pancreatic cancer patients treated with immune-cell therapy. Anticancer Res 38(7): 4353-4360, 2018. PMID: 29970573. DOI: 10.21873/anticanres.12736

31 Le DT, Uram JN, Wang H, Bartlett BR, Kemberling H, Eyring AD, Skora AD, Luber BS, Azad NS, Laheru D, Biedrzycki B, Donehower RC, Zaheer A, Fisher GA, Crocenzi TS, Lee JJ, Duffy SM, Goldberg RM, de la Chapelle A, Koshiji M, Bhaijee F, Huebner T, Hruban RH, Wood LD, Cuka N, Pardoll DM, Papadopoulos N, Kinzler KW, Zhou S, Cornish TC, Taube JM, Anders RA, Eshleman JR, Vogelstein B and Diaz LA Jr.: Pd-1 blockade in tumors with mismatch-repair deficiency. N Engl J Med 372(26): 2509-2520, 2015. PMID: 26028255. DOI: 10.1056/NEJMoa1500596

32 Overman MJ, McDermott R, Leach JL, Lonardi S, Lenz HJ, Morse MA, Desai J, Hill A, Axelson M, Moss RA, Goldberg MV, Cao ZA, Ledeine JM, Maglinte GA, Kopetz S and Andre T: Nivolumab in patients with metastatic DNA mismatch repairdeficient or microsatellite instability-high colorectal cancer (checkmate 142): An open-label, multicentre, phase 2 study. Lancet Oncol 18(9): 1182-1191, 2017. PMID: 28734759. DOI: 10.1016/S1470-2045(17)30422-9

33 Ward R, Meagher A, Tomlinson I, O’Connor T, Norrie M, Wu $\mathrm{R}$ and Hawkins $\mathrm{N}$ : Microsatellite instability and the clinicopathological features of sporadic colorectal cancer. Gut 48(6): 821-829, 2001. PMID: 11358903.

34 Llosa NJ, Cruise M, Tam A, Wicks EC, Hechenbleikner EM, Taube JM, Blosser RL, Fan H, Wang H, Luber BS, Zhang M, Papadopoulos N, Kinzler KW, Vogelstein B, Sears CL, Anders RA, Pardoll DM and Housseau F: The vigorous immune microenvironment of microsatellite instable colon cancer is balanced by multiple counter-inhibitory checkpoints. Cancer Discov 5(1): 43-51, 2015. PMID: 25358689. DOI: 10.1158/ 2159-8290.CD-14-0863

35 Barbee MS, Ogunniyi A, Horvat TZ and Dang TO: Current status and future directions of the immune checkpoint inhibitors ipilimumab, pembrolizumab, and nivolumab in oncology. Ann Pharmacother 49(8): 907-937, 2015. PMID: 25991832. DOI: $10.1177 / 1060028015586218$ 